American Journal of Animal and Veterinary Sciences 3 (1): 18-22, 2008

ISSN 1557-4555

(C) 2008 Science Publications

\title{
Study on the Correlations between Mineral Contents in Musculus Longissimus Dorsi and Meat Quality for Five Breeds of Pigs
}

\author{
REN Guang-zhi, WANG Ming, LI Zhen-tian, LI Xin-jian, CHEN Jun-feng, YIN qing-qiang \\ ${ }^{1}$ College of Animal Science and Veterinary Medicine, Henan Agricultural University, \\ Zhengzhou 450002, China \\ ${ }^{2}$ Henan Academy of Agricultural Science Zhengzhou 450002, China
}

\begin{abstract}
The correlations between mineral contents in musculus longissimus dorsi and meat quality for five breeds of pigs were studied in this experiment. Two imported breeds (Duroc and Yorkshires) and three local breeds (Huainan pig, Nanyang black pig, Queshan black pig) from Henan province of China were chosen in this trial. Ten $90 \mathrm{~kg}$ finishing pigs were selected randomly to slaughter from each breed. Mineral contents of $\mathrm{K}, \mathrm{Na}, \mathrm{Ca}, \mathrm{Fe}, \mathrm{Mn}, \mathrm{Cu}$ and $\mathrm{Zn}$ in musculus longissimus dorsi were detected by atomic absorption spectrophotometry and their correlations with meat quality were also analyzed. The results showed : (1) Mn and protein contents had no significant difference among all the breeds ( $>0.05)$, (2) $\mathrm{K}$ content in Duroc was higher than that in the other four breeds significantly $(\mathrm{p}<0.01)$, (3) Mineral contents of $\mathrm{Na}, \mathrm{Ca}, \mathrm{Mn}, \mathrm{Fe}, \mathrm{Cu}$ and $\mathrm{Zn}$ in local breeds were higher than that in the imported breeds significantly $(\mathrm{p}<0.01)$, (4) Marble stripes and meat colour in local breeds were superior to the imported ones, (5) Intramuscular fat content of local breeds was higher than that of the imported ones $(\mathrm{p}<0.01),(6)$ There was a significant positive correlation between $\mathrm{Zn}$ and the other mineral contents in the muscle $(\mathrm{p}<0.01$ or $\mathrm{p}<0.05)$, (7) Both $\mathrm{Cu}$ and $\mathrm{Fe}$ contents had a significant positive correlation with meat color $(\mathrm{p}<0.05)$, but negative correlation with drip loss $(\mathrm{p}<0.05),(8)$ There was a positive correlation between $\mathrm{Zn}$ and intramuscular fat content $(\mathrm{p}<0.01)$, but negative correlation between $\mathrm{Zn}$ and drip loss $(\mathrm{p}<0.01)$. In conclusion, Minerals in muscle had significant correlations with meat quality elements, but no significant correlations with meat protein and fat contents.
\end{abstract}

Key words: Mineral contents in musculus longissimus dorsi, Meat quality, Pig breeds, Correlation

\section{INTRODUCTION}

With the improvement of the consumption level of pork, meat quality becomes the most important character considered by the people. When the lean meat proportion was pursued excessively in the swine production, the hyperirritable gene frequency will be increased and meat quality is declined ${ }^{[1]}$. Both pig breed and nutritional management play the immportant roles in improving meat quality ${ }^{[2]}$. Trace minerals are essential for the growth and metabolism of pigs. In practice, extra addition of some vitamins and trace elements can improve the carcass characteristics, including moisture loss, meat color, marble stripes, etc., so the relationship between trace elements and meat characteristics are important for improving meat quality. But few researches were conducted to compare the effects of mineral elements on pork quality of the local and imported breeds. In this study, minerals of $\mathrm{K}$, $\mathrm{Na}, \mathrm{Ca}, \mathrm{Fe}, \mathrm{Mn}, \mathrm{Cu}$ and $\mathrm{Zn}$ in musculus longissimus dorsi in different breeds of pigs were detected and the correlations between meat quality and mineral contents were analyzed.

\section{MATERIALS AND METHODS}

The animals and breeds: Ten $90 \mathrm{~kg}$ finishing pigs were selected randomly from each breed (Huainan pig,

Corresponding Author: Qingqiang Yin, College of Animal Science and Veterinary Medicine, Henan Agricultural University, Zhengzhou 450002, China Tel: 86-371-63554237 Fax: 86-371-63558998 
Nanyang Black pig, Queshan Black pig, Duroc and Yorkshires pig) for slaughtering, respectively. The carcass were separated and $10 \mathrm{~g}$ fresh musculus longissimus dorsi were taken to be detected.

Reagent and equipment: The mixed acid: nitric acid $\left(\mathrm{HNO}_{3}\right.$, A.P) and perchloric acid $\left(\mathrm{HClO}_{4}\right.$, A.P) were mixed with 3:1. WFX-120 atomic absorption spectrophotometer (Beijing Reili analytical apparatus company) was used in this experiment.

\section{Evaluation method of meat quality}

Meat color: Middle portion of longissimus muscle were taken and stored in refrigerator at $0-4^{\circ} \mathrm{C}$ for $24 \mathrm{~h}$. The samples were cut open and measured with eyemeasurement by American system 5 score NPPC shade guide. It was permitted to give 0.5 score between two interstages. 1score $=$ Gray (abnormal colour), 2 scores $=$ light gray, 3 scores $=$ normal bright red, 4 scores $=$ slightly cardinal red (normal colour), 5 scores $=$ dull purple (abnormal colour).

Marble stripes: The segment in posterior rib of longissimus dorsi muscle was taken as the sample. The method of sample processing and test condition were done according to meat color evaluation. 1 score = Trace, 2 scres $=$ Gleam, 3 scores $=$ Jot, 4 scores $=$ Optimum dose, 5 scores $=$ excessive dose.

Water loss: The lumbar segment of longissimus muscle (storaged at $0-4^{\circ} \mathrm{C}$ for $24 \mathrm{~h}$ ) was cut into small pieces $(2 \mathrm{~cm} \times 3 \mathrm{~cm} \times 5 \mathrm{~cm})$. The sample was held with a thin wire after weighing, then sealed in a plastic bag kept untouched to insure the plastic bag have enough space to contain the spillage. The bag with sample was hung in a refrigerator at $0-4^{\circ} \mathrm{C}$ for $24 \mathrm{~h}$ and then the sample was taken out, extracted with filter paper and weighed.

The cooked meat rate: The right psoas of carcass was weighed after removing the ect-sarcolemma, boiled for 45 min with a $2 \mathrm{kw}$ electric cooker and then weighted after hanging in ambient temperature for $30 \mathrm{~min}$ to calculate the percentage of the cooked meat.

Tenderness: Took the fresh foreside of lumbar segments (1-5) of longissimus dorsi muscle as the sample, got rid of the surface fat, kept in a plastic bag for $24 \mathrm{~h}$ at $15-16^{\circ} \mathrm{C}$. The meat was taken out and kept at $0-4^{\circ} \mathrm{C}$ for $48 \mathrm{~h}$, kept at room temperature for $1 \mathrm{~h}$ and then dipped into a water bath at $75-80^{\circ} \mathrm{C}$ until the temperature of meat center got to $70^{\circ} \mathrm{C}$, taken out and cooled down to $20^{\circ} \mathrm{C}$. Cut the core into several chops $(1 \mathrm{~cm} \times 1 \mathrm{~cm} \times 2.5 \mathrm{~cm})$ and finally measured the shearing force with C-LM muscle tenderness instrument.

Estimating mineral contents in pork: Concentrations of calcium $(\mathrm{Ca})$, ferrum $(\mathrm{Fe})$, manganese $(\mathrm{Mg})$,copper $(\mathrm{Cu})$,zinc $(\mathrm{Zn})$ were determined by dry ashing — atomic absorption spectrophotometer and potassium and sodium by flame photometer according to operational manual.

Data analysis: All the data were primary analysized by EXCEL2003 and then multiply compared by Genaral Linear Modle of software SPSS11.5 and correlation analysized by correlate program.

\section{RESULTS AND DISCUSSION}

Concentrations of mineral elements in musculus longissimus dorsi: The results showed that five breeds of pigs had different contents of mineral element in musculus longissimus dorsi (Table 1). Duroc had more $\mathrm{K}$ level than that of Queshan Black pig $(\mathrm{p}<0.05)$, but there was no significant difference among the other breeds $(p>0.05$ ). Huainan pig had more $\mathrm{Na}$ content

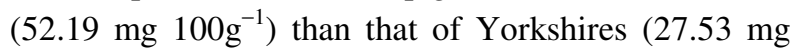
$100 \mathrm{~g}^{-1}$ ) and Duroc (39.29 $\mathrm{mg} 100 \mathrm{~g}^{-1}$ ) significantly $(\mathrm{p}<0.01)$. No significant differences were found among the five breeds for $\mathrm{Mn}$ contents. $\mathrm{Fe}, \mathrm{Ca}$ and $\mathrm{Zn}$ contents of muscle in local breeds were higher than that in the imported breeds $(\mathrm{p}<0.05)$. Queshan Black pig had the highest level of $\mathrm{Cu}$ among the five breeds $(\mathrm{p}<0.05)$. No significant difference were found for mineral contents except $\mathrm{Na}$ between Duroc and Yorkshire $(\mathrm{p}>0.05)$.

Nutrient compositions in musculus longissimus dorsi of different pig breeds: Table 2 showed that: Queshan black pig had less muscle moisture $(69.65 \%)$ than that of the Yorkshires $(72.00 \%)(\mathrm{p}<0.05)$, but there was no significant difference among the other pig breeds. No differences were observed in protein content among the different breeds. The contents of intramuscular fat for the local breeds were higher than that for the imported breeds $(\mathrm{p}<0.01)$. The ash content in the muscle of Queshan black pig was less than that of Huainan pig, Nanyang black pig and Yorkshires $(p<0.01)$, but without significant difference with Duroc $(\mathrm{p}>0.05)$. 
American J. Animal \& Vet. Sci., 3 (1): 18-22, 2008

Table 1: Mineral contents in musculus longissimus dorsi of different pig breeds (mg $100 \mathrm{~g}^{-1}$ )

\begin{tabular}{|c|c|c|c|c|c|c|c|}
\hline & $\mathrm{K}$ & $\mathrm{Na}$ & $\mathrm{Ca}$ & $\mathrm{Mn}$ & $\mathrm{Fe}$ & $\mathrm{Cu}$ & $\mathrm{Zn}$ \\
\hline Queshan black pigs & $340.15 \pm 23.53 b$ & $40.69 \pm 4.33 \mathrm{bB}$ & $2.64 \pm 0.37 \mathrm{aAB}$ & $0.0421 \pm 0.0165 \mathrm{a}$ & $8.08 \pm 0.89 \mathrm{a}$ & $3.16 \pm 0.18 \mathrm{~A}$ & $7.16 \pm 0.32 \mathrm{aAB}$ \\
\hline Nanyang black pigs & $357.52 \pm 14.25 \mathrm{ab}$ & $41.49 \pm 2.10 \mathrm{bAB}$ & $2.83 \pm 0.68 \mathrm{aA}$ & $0.0693 \pm 0.0158 \mathrm{a}$ & $11.51 \pm 3.47 \mathrm{a}$ & $2.23 \pm 0.12 \mathrm{bAB}$ & $6.47 \pm 0.36 \mathrm{abABC}$ \\
\hline Huainan pigs & $371.27 \pm 4.69 \mathrm{ab}$ & $52.19 \pm 2.78 \mathrm{aA}$ & $2.36 \pm 0.24 \mathrm{abAB}$ & $0.0933 \pm 0.0266 \mathrm{a}$ & $11.33 \pm 1.35 \mathrm{a}$ & $2.34 \pm 0.24 \mathrm{bAB}$ & $7.38 \pm 0.30 \mathrm{aA}$ \\
\hline Yorkshires & $373.96 \pm 8.91 \mathrm{ab}$ & $27.53 \pm 2.70 \mathrm{cC}$ & $1.30 \pm 0.36 \mathrm{bcAB}$ & $0.0701 \pm 0.0263 \mathrm{a}$ & $6.58 \pm 0.53 b$ & $1.67 \pm 0.17 \mathrm{~B}$ & $5.32 \pm 0.29 \mathrm{bcBC}$ \\
\hline Durocs & $391.26 \pm 4.94 \mathrm{a}$ & $39.29 \pm 1.27 \mathrm{bB}$ & $1.10 \pm 0.31 \mathrm{cB}$ & $0.0504 \pm 0.0160 \mathrm{a}$ & $5.01 \pm 0.88 \mathrm{~b}$ & $1.91 \pm 0.45 \mathrm{~B}$ & $4.94 \pm 0.91 \mathrm{cC}$ \\
\hline \multicolumn{8}{|c|}{$\begin{array}{l}\text { Note: The average with different lower case superscripts are different at } \mathrm{p}<0.05 \text {; the average with different capital superscripts are different at } \\
\mathrm{p}<0.01 \text {. The averages in the following tables had the same notes as this table } \\
\text { Table 2: Nutrient contents in musculus longissimus dorsi longissimus dorsi of pigs }(\%)\end{array}$} \\
\hline & \multicolumn{2}{|l|}{ Water } & \multicolumn{2}{|l|}{ Protein } & \multicolumn{2}{|c|}{ Intramuscular fat } & Ash \\
\hline Queshan black pigs & \multicolumn{2}{|c|}{$69.65 \pm 0.79 b$} & \multicolumn{2}{|l|}{$22.37 \pm 0.44 \mathrm{a}$} & \multicolumn{2}{|l|}{$6.09 \pm 0.80 \mathrm{aAB}$} & $0.88 \pm 0.19 \mathrm{cC}$ \\
\hline Nanyang black pigs & \multicolumn{2}{|c|}{$70.71 \pm 0.34 \mathrm{ab}$} & \multicolumn{2}{|l|}{$21.97 \pm 0.71 \mathrm{a}$} & \multicolumn{2}{|l|}{$5.58 \pm 0.53 \mathrm{aA}$} & $1.12 \pm 0.03 \mathrm{aA}$ \\
\hline Huainan pigs & \multicolumn{2}{|c|}{$71.01 \pm 0.80 \mathrm{ab}$} & \multicolumn{2}{|l|}{$22.03 \pm 0.51 \mathrm{a}$} & \multicolumn{2}{|l|}{$7.30 \pm 0.82 \mathrm{aA}$} & $1.04 \pm 0.03 \mathrm{aAB}$ \\
\hline Yorkshire & \multicolumn{2}{|c|}{$72.00 \pm 0.55 \mathrm{a}$} & \multicolumn{2}{|l|}{$23.29 \pm 0.74 \mathrm{a}$} & \multicolumn{2}{|l|}{$4.16 \pm 0.55 \mathrm{bBC}$} & $1.07 \pm 0.06 \mathrm{aA}$ \\
\hline Duroc & \multicolumn{2}{|c|}{$71.49 \pm 0.49 \mathrm{ab}$} & \multicolumn{2}{|l|}{$22.31 \pm 0.85 a$} & \multicolumn{2}{|l|}{$3.16 \pm 0.36 b C$} & $0.91 \pm 0.02 \mathrm{bBC}$ \\
\hline
\end{tabular}

Table 3: The quality of musculus longissimus dorsi in different pig breeds

\begin{tabular}{llllll}
\hline & Rate of cooked meat $(\%)$ & Tender rate $(\mathrm{kg})$ & Marble muscle (scores) & Meat color (scores) & Water loss $(\%)$ \\
\hline Queshan black pigs & $62.63 \pm 0.94 \mathrm{ab}$ & $3.12 \mathrm{v} 0.26 \mathrm{abA}$ & $3.75 \pm 0.88 \mathrm{abAB}$ & $2.75 \pm 0.11 \mathrm{~B}$ & $1.51 \pm 0.04 \mathrm{C}$ \\
Nanyang black pigs & $61.03 \pm 1.19 \mathrm{~b}$ & $2.89 \pm 0.11 \mathrm{abB}$ & $4.11 \pm 0.21 \mathrm{aA}$ & $3.17 \pm 0.08 \mathrm{~A}$ & $1.44 \pm 0.02 \mathrm{C}$ \\
Huainan pigs & $66.43 \pm 2.19 \mathrm{a}$ & $2.72 \pm 0.32 \mathrm{abAB}$ & $3.17 \pm 0.26 \mathrm{bBC}$ & $2.92 \pm 0.15 \mathrm{AB}$ & $2.62 \pm 0.07 \mathrm{~B}$ \\
Yorkshire & $62.24 \pm 1.01 \mathrm{ab}$ & $2.52 \pm 0.24 \mathrm{bAB}$ & $2.00 \pm 0.45 \mathrm{cD}$ & $2.42 \pm 0.11 \mathrm{C}$ & $4.83 \pm 0.11 \mathrm{~A}$ \\
Duroc & $62.60 \pm 1.14 \mathrm{ab}$ & $3.41 \pm 0.27 \mathrm{aA}$ & $2.42 \pm 0.58 \mathrm{cCD}$ & $2.67 \pm 0.08 \mathrm{~B}$ & $4.83 \pm 0.11 \mathrm{~A}$ \\
\hline
\end{tabular}

Table 4: Correlations among musculus minerals and meat quality

\begin{tabular}{|c|c|c|c|c|c|c|c|}
\hline & $\mathrm{Zn}$ & $\mathrm{Cu}$ & $\mathrm{Fe}$ & $\mathrm{Mn}$ & $\mathrm{Ca}$ & $\mathrm{K}$ & $\mathrm{Na}$ \\
\hline $\mathrm{Zn}$ & 1 & & & & & & \\
\hline $\mathrm{Cu}$ & $0.6732^{* *}$ & 1 & & & & & \\
\hline $\mathrm{Fe}$ & $0.4976^{* *}$ & 0.2715 & 1 & & & & \\
\hline $\mathrm{Mn}$ & 0.2709 & -0.1145 & $0.4074^{*}$ & 1 & & & \\
\hline $\mathrm{Ca}$ & $0.5026^{* *}$ & $0.3801^{*}$ & $0.6770^{* *}$ & 0.1360 & 1 & & \\
\hline K & -0.239 & -0.2683 & -0.0840 & -0.0881 & $-0.4741^{* *}$ & 1 & \\
\hline $\mathrm{Na}$ & $0.4232^{*}$ & 0.2697 & $0.3633^{*}$ & 0.2908 & 0.0864 & 0.1870 & 1 \\
\hline Moisture & -0.2358 & -0.2937 & 0.0571 & 0.0931 & 0.0185 & 0.1452 & -0.3184 \\
\hline Protein & -0.1896 & -0.2804 & 0.0947 & -0.1804 & -0.0144 & 0.1614 & -0.3453 \\
\hline Intramuscular fat & $0.4398^{*}$ & 0.2552 & 0.2710 & 0.0931 & 0.3304 & -0.2082 & $0.4405^{*}$ \\
\hline Ash & -0.0584 & -0.2424 & 0.3055 & 0.2876 & 0.1580 & 0.0859 & -0.0562 \\
\hline
\end{tabular}

Note: “*” represents $\mathrm{p}<0.05$ and “***" represents $\mathrm{p}<0.01$ 
American J. Animal \& Vet. Sci., 3 (1): 18-22, 2008

Table 5 correlations between musculus minerals and meat quality

\begin{tabular}{llllllll}
\hline & $\mathrm{Zn}$ & $\mathrm{Cu}$ & $\mathrm{Fe}$ & $\mathrm{Mn}$ & $\mathrm{Ca}$ & $\mathrm{K}$ & $\mathrm{Na}$ \\
\hline Color & 0.3465 & $0.3610^{*}$ & $0.5051^{*}$ & 0.0552 & 0.3164 & 0.0123 & $0.5305^{* *}$ \\
Marbling & 0.3445 & $0.3774^{*}$ & 0.2234 & -0.0667 & $0.4317^{*}$ & $-0.5149^{* *}$ & 0.3295 \\
Drip loss & $-0.5229^{*}$ & $-0.4324^{*}$ & $-0.4323^{*}$ & -0.0320 & $-0.5967^{* *}$ & $0.3943^{*}$ & $-0.3707^{*}$ \\
Cooked meat rate & 0.0049 & -0.1593 & -0.1533 & -0.1250 & -0.2760 & 0.1743 & 0.2721 \\
Tenderness & -0.233 & 0.1467 & -0.3224 & -0.2603 & $-0.4392^{*}$ & 0.0860 & 0.1251 \\
\hline
\end{tabular}

Note: “*” represents $\mathrm{p}<0.05$ and “**” represents $\mathrm{p}<0.01$

The quality of musculus longissimus dorsi in different breeds of pigs: The rate of cooked meat of Huainan pig was more than that of Nanyang black pig $(\mathrm{p}<0.05)$, but without significant difference among the other breeds $(p>0.05)$. The tenderness of muscle was best for Duroc and Queshan black pig $(\mathrm{p}<0.01)$, followed by Nanyang black pig, Huainan pig and Yorkshires. Duroc and Yorkshires had lower marbling score significantly than Queshan black pig, Huainan pig and Nanyang black pig $(\mathrm{p}<0.01)$ and difference was also observed between Huainan pig and Nanyang black pig $(\mathrm{p}<0.01)$. Meat color of Nanyang black pig were significant different from that of Queshan black pig, Duroc and Yorkshires $(\mathrm{p}<0.01)$ and the difference also existed between Yorkshires and Huainan pig $(\mathrm{p}<0.01)$. Water loss in muscle of the imported breeds was higher than that of the local breeds $(\mathrm{p}<0.01)$ Table 3.

Correlation analysis of mineral contents and meat quality: Correlations amoung mineral contents in musculus longissimus dorsi and meat quality were analyzed Table 4 and 5. There was a significant positive correlation between $\mathrm{Zn}$ and $\mathrm{Cu}, \mathrm{Fe}, \mathrm{Ca}(\mathrm{p}<0.01)$ and $\mathrm{Na}$ $(\mathrm{p}<0.05) . \mathrm{Cu}$ had a significant positive correlation with $\mathrm{Ca}(\mathrm{p}<0.05), \mathrm{Fe}$ had a significant positive correlation with $\mathrm{Mn}, \mathrm{Na}(\mathrm{p}<0.05)$ and $\mathrm{Ca}(\mathrm{p}<0.01), \mathrm{Ca}$ had a negative correlation with $\mathrm{K}(\mathrm{p}<0.01)$. Moisture, protein and ash contents in muscle had no correlation with the minerals. Both $\mathrm{Zn}$ and $\mathrm{Na}$ had significant positive correlations with the content of intramuscular fat $(\mathrm{p}<0.01), \mathrm{Zn}$ had a negative correlation with water loss $(\mathrm{p}<0.01)$. Both Marbling and meat color had positive correlations with $\mathrm{Cu} \quad(\mathrm{p}<0.05)$, but had negative correlations with water loss $(\mathrm{p}<0.01)$. Fe had a positive correlation with meat color $(\mathrm{p}<0.01)$, but a negative correlation with drip loss $(\mathrm{p}<0.05)$. Ca had a positive correlation with Marbling $(\mathrm{p}<0.01)$, but a negative correlation with water loss $(\mathrm{p}<0.01)$ and tenderness $(\mathrm{p}<0.05)$. $\mathrm{K}$ had a negative correlation with Marbling $(\mathrm{p}<0.01)$, but a positive correlation with water loss $(\mathrm{p}<0.05)$. Na had a positive correlation with meat color $(\mathrm{p}<0.01)$, but a negative correlation with water loss $(\mathrm{p}<0.05)$.

The contents of minerals in musculus longissimus dorsi: The contents of $\mathrm{K}$ and $\mathrm{Na}$ in muscle determined in this experiment are in agreement with the data measured by $\mathrm{Li}$ lianghua ${ }^{[3]}$. Both $\mathrm{Na}$ and $\mathrm{Ca}$ contents in the imported breeds were less than that of local breeds. There is no significant deviation of Mn contents among different breeds, which indicated that muscle tissue was not the place of Mn enriching. Fe contents in local pigs were more than that of the imported breeds, showing that Fe ingestion of local pigs was better than that of the imported breeds. $\mathrm{Zn}$ content measured in this experiment was different from the reports by Lou and $\mathrm{Li}^{[4]}$, but agreement with $\mathrm{Jin}^{[5]}$. The breeds, sample-part and metropolis might produce the differences.

The relationship between pork quality and breeds: The contents of moisture and ash were agreement with the former report ${ }^{[15]}$. The contents of intramuscularly fat in Queshan Black pig, Nanyang Black pig and Huainan pig were consistent with the report for local breeds ${ }^{[6]}$. There was no significant difference in cooked meat rate among different breeds, but the water loss in local breeds was lower than that of the imported breeds, which indicated that local pigs lost little water during the storage and had more commercial value. Generaly, marbling reflects the distribution of intramuscularly fat, the results showed that the three local breeds were better than the imported ones, it can help to improve the flavour and tenderness of the meat.

The corelation of musculus minerals with meat quality Myoglobin and hemoglobin have great effect 
on meat color and $\mathrm{Fe}$ is the essential ingredient of the myoglobin and hemoglobin. When the myoglobin (madder red) is combined with oxygen, it forms oxymyoglobin (bright red), when myoglobin is oxidized to metmyoglobin, i.e., $\mathrm{Fe}^{2+}$ is oxidized to $\mathrm{Fe}^{3+}$ the color will change to dark brown ${ }^{[7]}$. It was reported that adding $100 \mathrm{ppm}$ fuscous complex into pig's diet could improve meat color during the srorage for sale ${ }^{[8]}$. It indicated that $\mathrm{Fe}$ had positive correlation with color $(\mathrm{p}<0.01)$. The relationship of elements and meat color shows that certain contents of minerals can improve meat color, but the result may be opposite if the contens are too high. $\mathrm{Zn}, \mathrm{Mn}, \mathrm{Cu}$ and $\mathrm{Fe}$ are the important ingredients of SOD, they can help to change superoxide anion to $\mathrm{H}_{2} \mathrm{O}_{2}$, which can produce water with the help of peroxydase to protect integrity of cell membrane, to decrease the damage of the free radical to the meat color, thus improve meat quality ${ }^{[9]}$. But the excess Fe and $\mathrm{Cu}$ will accelerate lipid peroxidation, so the contents of minerals would be kept in appropriate level. Content of $\mathrm{K}$ is the most affluent in muscle, the balance of $\mathrm{K}$ and $\mathrm{Na}$ is essential for maintaining the water holding capacity and appropriate $\mathrm{pH}$ in the tissues. The presence of $\mathrm{Ca}^{2+}$ will activate calcium-dependent proteinase increase proteolysis of muscle to improve the tenderness of muscle. Duckeet et al. drenched calcium adhesive to cattle before killed (3-6 h), the tenderness of beef was improved ${ }^{[10]}$. This result showed that calcium level and tenderness were correlative. Zhang found that adding $\mathrm{Zn}$ to feed had quadratic effects on the subcutaneous fat thickness ${ }^{[11]}$. This research also indicated that $\mathrm{Zn}$ content of muscles had positive correlation with intramuscularly fat.

\section{CONCLUSIONS}

Various breeds of pigs had different contents of minerals in musculus longissimus dorsi. Mn content had no significant difference among all breeds. K content in Duroc was higher than that of the other four breeds significantly. Musculus minerals of $\mathrm{Na}, \mathrm{Ca}, \mathrm{Mn}$, $\mathrm{Fe}, \mathrm{Cu}$ and $\mathrm{Zn}$ in local breeds were higher than that in the imported breeds significantly.

There was a significant positive correlation between $\mathrm{Zn}$ and the other mineral elements in the muscle. Both $\mathrm{Cu}$ and $\mathrm{Fe}$ contents had significant positive correlations with meat color, but negative correlations with drip loss. Zn had a positive correlation with intramuscular fat, but a negative correlation with drip loss.
Intramuscular fat contents in local breeds were higher than that of the imported breeds, but the content of protein in muscle had no significant difference among the different breeds.

\section{REFERENCES}

1. Lundstron, K., B. Essen-Gustavson and M. Undgren, 1989. Effert of halothane genetype on musule metabolism at slaughter and its relationship with meat quality: A whithinlitter comparison. Meat. Sci., 25 (1): 251-263.

2. Li Xue-wei, Xiao Yong-zha and Zhang Jun-sheng, 1992. A comparitive study on meat and fat quality of Sichuan pig with foreign and crossbred pigs. J. Sichuan Agric. Univ., 2: 285-290.

3. Li Liang-hua, Wang Ping and Zhu Qiao-mei, 2006. Analysis of correlation between mineral content and meat quality in pork. Hubei J. Anim. Vet. Sci., 6: 8-10.

4. Lou Yuan-li and Li Ming-fu, 1997. The determination of micro- $\mathrm{Cu}-\mathrm{Pb}-\mathrm{Zn}-\mathrm{Cd}$ in meat samples by atomic absorption spectrophotometry. Henan Geol., 15 (4): 307-310.

5. JIN Bang-quan and Tao Li, Ying Qing-hong, 2001. Relationship between the content of $\mathrm{Ca}, \mathrm{P}, \mathrm{Mg}$, $\mathrm{Mn}, \mathrm{Zn}$ of myoplasm and the growth of muscle,bone in swine. Anim. Husbandry Vet. Med., 33 (1): 10-12.

6. Zhang Wei-li, 2006. Idea on pig culture and quality of pork. Swine Ind. Sci., 4: 28-30.

7. Chen Dai-wen, Zhang Ke-ying and $\mathrm{Hu} \mathrm{Zu}-\mathrm{yu}$, 2002. The mechanism for developing pork quality traits. J. Sichuan Agric. Univ., 20 (1): 60-66.

8. Ludden, T., 2004. Dietary organic iron may help improve quality of retail pork. Feedstuffs, 12: 9-14.

9. Wu Hong-zhong, Yuan Tao and $\mathrm{Xu}$ Ji-cheng, 2003. Influence of feed nutrients on meat quality. Feed Rev., 7: 27-29.

10. Purchas R.W., D.L. Burnham and S.T. Morris, 2002. Effects of growth potential and growth path on tenderness of beef longissimus muscle from bulls and steers. J. Anim. Sci., 80: 3211-3221.

11. Zhang Geng, Xiao Shu-hua and He Jun, 2007. Summary on formation mechanism of inferior meat and methods of micronutrients on meat quality control. Pig's Today, 1: 39-44. 